\title{
Implication Of Provisions Article 58 Paragraph (2) Law Number 15 Of 2019 Concerning Amendments To Law Number 12 Of 2011 Concerning The Formation Of Laws And Regulations On The Mechanism Of Harmonizing, Unifying And Consolidating The Conception Of Draft Regional Regulations
}

\author{
Muhammad Ali Badary \\ badary_ali@yahoo.co.id \\ Lampung Regional Office of the Ministry of Law and Human Rights
}

Submitted: Sep 17, 2020; Reviewed: Okt 1, 2020; Accepted: Okt 26, 2020

Keywords: Implication; Harmonization.

DOI:

https://doi.org/10.25041/constitutionale.v1i1.2123
Abstract

Article 58 paragraph (2) of Law Number 15 of 2019 concerning Amendments to Law Number 12 of 2011 concerning the Formation of Legislative Regulations changes the position of the central government in the process of harmonizing, unifying and consolidating the conception of draft regional regulations. The formulation of norms and laying of norms of Article 58 paragraph (2) of Law Number 15 of 2019 has resulted in normative legal consequences on the authority of regional apparatuses which have been coordinating harmonization, unification and consolidation of the conception of draft regional regulations proposed by regional heads and also resulting in the position of the central government to participate in harmonizing the draft regional regulations initiated by the Regional People's Representative Council. This 
study aims to identify the normative problems posed by Article 58 paragraph (2) of Law Number 15 of 2019 , especially with regard to the mechanism of harmonization, unification and consolidation of the conception of draft regional regulations. This type of research is a type of normative research and the approach used in this study is a statute approach, a conceptual approach, and an analytical approach. The results of this study indicate that Article 58 paragraph (2) of Law Number 15 of 2019 raises normative problems in at least two things, namely the institutional relationship between vertical agencies in the regions and local governments which both have the authority to harmonize, unify and consolidate the conception of draft regional regulations. The types of draft regional regulations are harmonized by the ministry or agency that administers government affairs in the field of Formulation of Legislation. This problem arises because the formulation of norms and the placement of the norms of Article 58 paragraph (2) of Law Number 15 of 2019 are inaccurate so that there needs to be a revision of the formulation or laying of norms regulating the authority of ministries or institutions that carry out government affairs in the field of Regulatory Formation. Legislation in the harmonization, unification and strengthening of the conception of draft regional regulations. 


\section{A. Introduction}

Article 1 paragraph (3) of the 1945 Constitution of the Republic of Indonesia affirms that the Indonesian state is a constitutional state. As a rule of law, the law is placed as an effective means of managing the life of the nation and state ${ }^{1}$. The law itself in a country with a continental European legal system is often interpreted as legislation ${ }^{2}$.Legislation has a central role in legal development in Indonesia because legislation are not only a codification for norms and values that have been applied in society but also for creating modifications in the life of society itself. ${ }^{3}$.

Legislation that is structured in stage in Indonesia has the consequence that a lower legal rule originating from a higher legal rule and a lower legal rule is not allowed to conflict with the higher legal rule. ${ }^{4}$. And in the context of the formation of regional regulations, there are stages that must be taken as a mechanism to maintain and implement the principles of the order of laws and regulations, namely the stages of harmonization, unification and consolidation of concepts. ${ }^{5}$.

Harmonization is an important process in the formation of laws and regulations. Through this process of harmonization, the unity of the norm system, especially the existing norms in regional regulations and the norms of higher legislation, can be realized because harmonization is not only avoiding overlapping or conflicting regulations but more than that so that the legislation created and the ease of positive law can carry out its function properly in society. ${ }^{6}$.

Regional regulations, which are legal instruments for the administration of regional governments, have the potential for enormous disharmony. Regional autonomy has resulted in the formation of massive regional regulations but they are not formulated in a structured and systematic manner ${ }^{7}$ so that there are allegedly $25 \%$ of the total regional legal products in the form of regulations throughout Indonesia that conflict with the higher legislation. ${ }^{8}$ This condition is very worrying especially at this time the central government no longer has the authority to cancel regional regulations after the Constitutional Court decisions Number 137/PUU-XIII/2015 and Number 56//PUU-XIV/2016 which canceled the article 251 paragraph (2), paragraph (3), paragraph (4) and paragraph (8) of Law Number 23 of 2014 concerning Regional Government. In the absence of central government authority to cancel regional regulations, preventive measures are the only way for the central government to minimize the potential for regional regulations that conflict with higher legislation.

Central government control over the formation of regional regulation norms has actually been provided, namely through the mechanism of harmonization, unification, and strengthening of the conception of regional regulations as confirmed in Article 58 paragraph (2) of Law Number 12 of 2011 concerning the Formation of Legislation. Unfortunately, the

\footnotetext{
${ }^{1}$ Haposan Siallagan., "Penerapan Prinsip Negara Hukum di Indonesia”, Sosiohumaniora, (Bandung: Unpad Press, 2016), pg. 132.

${ }^{2}$ Delfina Gusman., "Urgensi Naskah Akademik Dalam Pembentukan Peraturan Perundang-Undangan yang Baik",MasalahMasalah Hukum, (Semarang: Fakultas Hukum Universitas Diponegoro, 2011), pg 297.

${ }^{3}$ Maria Farida Indrati, 2002,Ilmu Perundang-Undangan: Jenis, Fungsi dan Materi Muatan, Yogyakarta: Kanisius,pg. 2.

${ }^{4}$ Zainal Arifin Hoesein., "Pembentukan Hukum Dalam Perspektif Pembaharuan Hukum”,Jurnal Rechts Vinding (Jakarta: Pusat Analisis dan Evaluasi Hukum Nasional Badan Pembinaan Hukum Nasional Kementerian Hukum dan HAM RI, 2011), pg. 311.

${ }^{5}$ Ni'matul Huda., "Kedudukan Peraturan Daerah Dalam Hierarki Peraturan Perundang-Undangan”,Jurnal HukumIUS QUIA IUSTUM, (Yogyakarta: Fakultas Hukum Universitas Islam Indonesia, 2006), pg. 36.

${ }^{6}$ Bayu Dwi Anggono., "Harmonisasi Peraturan Perundang-Undangan di Bidang Penanggulangan Bencana, $M I M B A R$ HUKUM, ( Yogyakarta: Fakultas Hukum Universitas Gajah Mada, 2010), pg 386.

${ }^{7}$ Ibnu Sina Chandranegara., "Bentuk-Bentuk Perampingan dan Harmonisasi Regulasi". Jurnal Hukum IUS QUIA IUSTUM, (Yogyakarta: Fakultas Hukum Universitas Islam Indonesia, 2019), pg. 436.

8 Pernyataan Dirjen Otonomi Daerah Kementerian Dalam Negeri "Perda Tumpang Tindih denga aturan yang Lebih Tinggi", https://mediaindonesia.com/read/detail/211482-kemendagri-25-perda-tumpang-tindih-dengan-aturan-yang lebih-tinggi, diakses tanggal 02 September 2020.
} 
construction of norms contained in this article uses the word "can" to express the involvement of the vertical agencies of the ministries that carry out government affairs in the legal sector $^{9}$ so that normatively the involvement of the central government in the process of harmonizing regional regulations is not a procedural obligation. In addition to harmonization, the central government's control mechanism for the formulation of regional regulation norms is through a mechanism called evaluation and facilitation as confirmed in the Minister of Home Affairs Regulation Number 80 of 2015 concerning the Formation of Regional Legal Products as amended by the Minister of Home Affairs Regulation Number 120 of 2018, however the institution that carries out the facilitation and evaluation function is not the ministry that carries out government affairs in the legal sector but the Ministry of Home Affairs for Provincial Regulations and Provincial Government for Regency/City Regulations ${ }^{10}$.

Construction of the norms of Article 58 paragraph (2) of Law Number 12 Year 2011 which originally placed the vertical agencies of the ministry in charge of legal affairs as parties that could be involved in harmonizing, unifying, and consolidating the conception of draft regional regulations coordinated by the regional Legal Bureau/Division government, currently based on Article 58 paragraph (2) of Law Number 15 of 2019 concerning Amendments to Law Number 12 of 2011 concerning the Formation of Laws and Regulations placing the central government through an institution that administers government affairs in the field of forming legislation as the party implementing the harmonization, unification, and consolidation of the conception of the draft regional regulation comes from the executive (regional head). This change in the construction of norms has a broad impact on the position of institutions that have the authority and obligations in harmonizing, unifying, and strengthening the conception of draft regional regulations.

The further impact of the amendment of the norm construction of Article 58 paragraph (2) of Law Number 15 of 2019 regarding the control function of the central government through its institutions/ministries in harmonizing, consolidating, and unifying the conception of draft regional regulations originating from Regional People's Representative Council (DPRD). DPRD is the leading sector for the formation of regional regulations ${ }^{11}$ that are institutionally equal in degree to regional governments and there is no regional regulation that is not formed jointly between the two institutions. In such a condition, the mechanism for forming regional regulations, whether initiated by the DPRD or the Regional Government, should have the same mechanism.

Based on these two impacts, it is deemed necessary to conduct a normative juridical study of the normative implications of the enactment of the provisions of Article 58 paragraph (2) of Law Number 15 of 2019 on the mechanism of harmonization, unification, and consolidation of the conception of draft regional regulation through statue approaches, conceptual approaches and an analytical approach to describe errors in the formulation and placement of norms as well as disharmony between laws that regulate harmonization, unification, and consolidation of the conception of draft regional regulation.

\footnotetext{
9 Pasal 58 ayat (2) Undang-Undang Nomor 12 Tahun 2011 tentang Pembentukan Peraturan Perundang-Undangan "Pengharmonisasian, pembulatan, dan pemantapan konsepsi Rancangan Peraturan Daerah Provinsi yang berasal dari Gubernur dikoordinasikan oleh biro hukum dan dapat mengikutsertakan instansi vertical dari kementerian yang menyelenggarakan urusan pemerintahan di bidang hukum".

${ }^{10}$ Pasal 87 sampai dengan Pasal 90 untuk Fasilitasi Pembentukan Produk Hukum Daerah dan Pasal 91 sampai dengan Pasal 97 Permendagri Nomor 80 Tahun 2015 sebagaimana telah diubah dengan Peraturan Menteri Dalam Negeri Nomor 120 Tahun 2018 untuk evaluasi Peraturan Daerah.

${ }_{11}$ Nanda Pratama Sukoco., "Peran Badan Legislasi Dalam Pembentukan Peraturan Daerah Inisiatif Dewan Perwakilan Rakyat Daerah Provinsi Jawa Timur", Jejaring Administrasi Publik (Surabaya: Fakultas Hukum Universitas Airlangga, 2012), pg. 92.
} 


\section{B. Discussion}

\section{Central Government Involvement in Harmonizing Draft Regional Regulations}

Legislation that is arranged in stages in the legislation system in Indonesia has a consequence where the relationship between one legislation norms to another is called a super and sub-coordinated relationship in a spatial context. The norms of higher legislation are called superior while those below are called inferior. ${ }^{12}$ In such a context, the attachment of a norm is overpowering against other norms or it can be said that the validity of a legislation norm is very dependent on the validity of the higher legislation norms. The attachment of these norms makes the legislation system formed in stages does not provide room for disharmony of legislation norms. Regional regulations are normatively grouped as one type of legislation; ${ }^{13}$ therefore the formation of regional regulation norms can be ascertained from and depends on their validity from legislation which is hierarchically higher in level.

Regional regulations themselves in the hierarchy of legislation contained in Article 7 paragraph (1) of Law Number 12 of 2011 are placed in the last order under the Presidential Regulation. This condition means that in the formulation of regional regulation norms, it is mandatory to be based on the norms of the higher legislation. The number of legislations that must be used as guidelines in the formulation of regional regulation norms is difficult and harmonization is the most relevant procedure to minimize the occurrence of norm disharmony. ${ }^{14}$

The urgency of central government involvement in the formation of regional regulation norms is not only based on the theory of one unit of forming as the application of the hierarchical concept of legislation in the legislation system in Indonesia but also due to the application of the concept of a unitary state (eenheidsstaat). In a unitary state, there is a principle that all governmental affairs in a unitary state remain unanimous (eenheid) and the highest authority in that country is the central government. ${ }^{15}$.The consolidation of the hierarchical concept of legislation and the concept of a unitary state is the basis for the central government to participate in controlling the government units under it, namely the provincial, district/city governments. One of the supervision forms of the central government on the administration of regional governments is through supervision/control of the norms of legislation, which is often known as the general norm control mechanism. The main objective of this control is to keep the constitutional principles contained in the constitutional law and other constitutional legislations not being deviated or violated so that an institution and procedures for supervision are needed. ${ }^{16}$ General norm mechanisms are manifested in three forms, namely executive review, legislative review, and judicial review. ${ }^{17}$

Apart from these three forms of control, specifically for the formation of regional regulations, there is still a central government control mechanism for norm formation at the regional government level, namely through the abstract preview procedure. The abstract preview mechanism is the central government control mechanism for the formation of regional regulation norms when the regulation has not been passed. ${ }^{18}$ This procedure

\footnotetext{
12 Jimly Asshiddiqie, dan M. Ali Safaat, 2006, Theory Hans Kelsen Tentang Hukum, Jakarta: Cet I. Sekretariat Jendreral \& Kepaniteraan Makamah Konstitusi RI, pg. 110.

${ }_{13}$ Arifin, "Eksistensi Peraturan Daerah Dlaam Sistem Hukum Nasional dan Implementasinya Terhadap Otonomi”, JURNAL ILMU HUKUM LEGAL OPINION, (Palu: Fakultas Hukum Universitas Tadulako, 2015),

${ }^{14}$ There also other regulations that could be applied apart from Article 8 Undang-Undang Nomor 12 Tahun 2011.

${ }^{15}$ Supriyadi., "Peraturan Daerah, Antara Kepentingan Pemerintah Pusat dan Pemerintah Daerah",Jurnal Cakrawala Hukum, (Malang: Universitas Merdeka, 2016), pg. 137.

${ }^{16}$ Mohammad Mahrus Ali, "Konstitusionalitas dan Legalitas Norma dalam Pengujian Undang-Undang Terhadap UndangUndang Dasar 1945”, Jurnal Konstitusi, (Jakarta: Kepaniteraan dan Sekretariat Jenderal Mahkamah Konstitusi Republik Indonesia, 2015), pg. 175.

${ }^{17}$ Jimly Asshiddiqie, 2010, Perihal Undang-Undang, Jakarta: PT. Raja Grafindo Persada, pg. 108.

${ }^{18}$ Ibid, pg 108
} 
emphasizes the preventive element of a test, because the goal is to maintain the utility (doelmatigheid) and legality (rechtmatigheid) of legislation before it is passed and declared to be binding for the public. ${ }^{19}$ In practice, this mechanism is manifested in many different models, some of which are known in the current legislation formulation mechanism, namely Harmonization, Facilitation, and Harmonization Evaluation.

In line with the concept of general norm control mechanism, Bagir Manan as quoted by Widodo Ekathahjana stated that there are two models of supervision of the autonomous government, namely preventive supervision and repressive supervision. The two models of supervision are shown in the legal products produced by the regions, and the supervision of the actions of regional government organs which are carried out through the authority to ratify in preventive supervision and the authority to cancel or postpone in repressive supervision. ${ }^{20}$ Preventive supervision or abstract preview is carried out in the framework of developing and supervising the regional regulations that have been established by the Provincial or Regency/City governments whether the regional regulations contradict the provisions of higher legislations, public interest and morality. ${ }^{21}$.

Preventive supervision in the formation of regional regulations carried out by the central government to regional governments is an internal supervision that is only in the executive domain. ${ }^{22}$ One of these preventive supervisions is manifested in the form of stages of harmonizing legislation which is carried out in two formulation steps, namely harmonization of policy formulation (regulatory system) and harmonization of material (substance). ${ }^{23}$ These two steps lead to the unification of the legislation formation system and the unification of regulatory norms in existing legislation.

\section{Implications of the Provisions of Article 58 Paragraph (2) of Law Number 15 Year 2019 on the Position of Institutions Having Authority and Obligation in Harmonizing, Rounding and Consolidating Conception of Draft Regional Regulations}

In preparing the structure of the State institution, Indonesia applies the theory of separation of power proposed by Montesquieu with the concept of trias politica where state power is divided into three, namely executive, legislative and judiciary, where each branch of power cannot interfere with other powers. ${ }^{24}$ The state institutional structure which is divided into three is similar and is applied similarly in the context of regional government administration but without judicial power where the regional government is the holder of executive power and the DPRD is the holder of legislative power, although in some cases there is still much debate as to whether the position of DPRD in the region is exactly the same as the DPR RI at the central level. ${ }^{25}$ Apart from being institutional, the mechanism for filling

\footnotetext{
${ }^{19}$ Enrico Simanjuntak., "Pengujian Perda dan Perdes Pasca Perubahan UU Pemda dan UU Desa", Jurnal Konstitusi, (Jakarta: Kepaniteraan dan Sekretariat Jenderal Mahkamah Konstitusi Republik Indonesia, 2016), pg. 643.

${ }^{20}$ Widodo Ekathahjana, 2008, Pengujian Peraturan Perundang-Undangan dan Sistem Peradilannya di Indonesia, Bandung: Pustaka Sutra, pg. 43.

${ }^{21}$ Aditia syaprillah., "Strategi Harmonisasi Penyusunan Peraturan Daerah Melalui Mekanisme Executive Preview. Borneo Law Review, (Tarakan: Pasca Sarjana Magister Hukum Universitas Borneo Tarakan, 2019), pg. 98.

${ }^{22}$ Derita Prapti Rahayu., "Pengawasan Preventif Sebagai Kontrol Pusat Terhadap Daerah di Era Reformasi”, PADJAJARAN Jurnal Ilmu Hukum, (Bandung, Fakultas Hukum Universitas Padjajaran, 2015), pg. 451.

23 Firdaus; Donny Michael., "Implementasi Peraturan Menteri Hukum dan HAM Nomor 23 Tahun 2018 tentang Pengharmonisasian Rancangan Peraturan Menteri, Rancangan Peraturan Lembaga Pemerintah Non Kementerian Atau Rancangan Peraturan Dari Lembaga Non structural Oleh Perancang Peraturan Perundang-Undangan”, Jurnal Penelitian Hukum De Jure, (Jakarta: Badan Penelitian dan Pengembangan Hukum dan HAM Kementerian Hukum dan HAM RI, 2019), pg. 324.

${ }_{24}$ Jimly Asshiddiqie, 2006, Pengantar Hukum Tata Negara Jilid II, Jakarta: Sekretariat Jenderal dan Kepaniteraan Mahkamah Konstitusi, pg. 15.

${ }^{25}$ Masaih banyak yang berbeda pendapata mengenai kedudukan DPRD apakah DPRD memiliki kedudukan secara tegas sebagai lembaga (badan) legislatif sebagaimana dikenal dalam konsep trias politica atau akan diposisikan sebagai salah satu
} 
the positions of regional heads and members of regional legislatures (DPRD) has the same mechanism as the mechanisms for filling the positions of head of State and legislators at the central level (DPRRI).

In the context of the formation of regional regulations, the regional government as the executive and the DPRD as the legislative normatively have the authority to form regional regulations. The regional government has a regional apparatus that has a specific task in the formation of regional regulations, namely the Legal Bureau/Legal Department which is part of the regional secretariat where one of its functions is to coordinate the formulation of regional policies. ${ }^{26}$ Meanwhile, the DPRD has DPRD organs that are tasked with coordinating the implementation of DPRD duties in the field of regional regulation formation under the name of the Regional Regulation Formation Body. The institutional pattern that handles the formation of regional regulations is similar to the institutional pattern that deals with the formation of laws at the central government level, where the Ministry of Law and Human Rights at the central level carries out functions such as the Legal Bureau/Legal Division at the regional government level and the Legislation Body at the DPRRI level carrying out functions such as the Agency. Establishment of Regional Regulations at the regional legislative level.

Law Number 12 of 2011 before the amendment has a viewpoint similar to the institutional pattern described in the previous paragraph. We can observe this from the structure of norming related to the harmonization mechanism, the unification and consolidation of the draft law conception and the harmonization mechanism, the unification and strengthening of the draft regional regulation conception. ${ }^{27}$ Law Number 12 of 2011 prior to the amendment places the authority to harmonize, unify and consolidate the conception of the draft regional regulations in the legal bureau / legal division (local government) and the regional regulation formation body (DPRD) while the involvement of vertical agencies is only incidental or not an obligation. because the formulation of the norm of Article 58 of Law Number 12 Year 2011 uses the word "dapat" or "able". ${ }^{28}$ With the construction of norms of Article 58 of Law Number 12 Year 2011, the process of harmonizing, unifying and consolidating the conception of draft regional regulations has been factually carried out by the regional government and DPRD in accordance with their respective authority, while the involvement of vertical agencies in the regions is involved. in the event that there is a mere need, both technically, for the formation of statutory regulations, as well as a need in substance to contain the norms of a draft regional regulation.

Law Number 15 of 2019 concerning Amendments to Law Number 12 of 2011 has a different point of view related to the mechanism for the formation of regional regulations where in the formulation of the provisions of Article 58 paragraph (2) it is stated that "Harmonizing, unifying, and strengthening the conception of the Draft Regulation Provincial regions originating from the Governor are carried out by ministries or institutions that carry out government affairs in the field of the Formation of Legislation." The formulation of the

unsur penyelenggara pemerintahan daerah semata. Asmawi., “ Dewan Perwakilan Rakyat Daerah (DPRD) Dalam PerundangUndangan Pemerintahan Daerah dan Lembaga Legislatif Daerah”. Jurnal Cita Hukum, (Jakarta: Fakultas syariah dan Hukum Universitas Islam Negeri Syarif Hidayatullah Jakarta, 2014), pg. 5.

${ }^{26}$ Pasal 7 ayat (4) huruf a Peraturan Pemerintah Nomor 18 Tahun 2016 tentang Perangkat Daerah

${ }^{27}$ Rumusan norma serupa dapat kita temukan dalam Pasal 46 ayat (2) dan Pasal 47 ayat (3) Undang-Undang Nomor 12 Tahun 2011 untuk Pengpengharmonisasian, pembulatan dan pemantapan konsepsi rancangan undang-undang. Dan Pasal 58 Undang-Undang Nomor 12 Tahun 2011 untuk pengharmonisasian, pembulatan dan pemantapan konsepsi rancangan peraturan daerah.

${ }^{28}$ Pasal 58 Undang -Undang Nomor 12 Tahun 2011 menyatakan bahwa:

(1) Pengharmonisasian, pembulatan, dan pemantapan konsepsi Rancangan Peraturan Daerah Provinsi yang berasal dari DPRD Provinsi dikoordinasikan oleh alat kelengkapan DPRD Provinsi yang khusus menangani bidang legislasi.

(2) Pengharmonisasian, pembulatan, dan pemantapan konsepsi Rancangan Peraturan Daerah Provinsi yang berasal dari Gubernur dikoordinasikan oleh biro hukum dan dapat mengikutsertakan instansi vertikal darikementerian yang menyelenggarakan urusan pemerintahan di bidang hukum. 
provisions of Article 58 paragraph (2) of Law Number 15 of 2019 significantly eliminates the position of the Legal Bureau as the party that originally coordinated the harmonization, unification and consolidation of the conception of the Draft Provincial Regulation from the Governor (Law Number 12 of 2011) be a party that may be involved in Harmonizing, unifying, and consolidating the conception of the Provincial Regulation Draft from the Governor (Law Number 15 of 2019) because the construction of the norms of Article 58 paragraph (2) of Law Number 15 of 2019 does not explicitly state the existence of a Legal Bureau in the process of harmonizing, unifying, and consolidating the conception of the Draft Provincial Regulation originating from the Governor.

The provisions of Article 58 paragraph (2) of Law Number 15 Year 2019 seem to strengthen the role of the central government through its apparatus to carry out the abstract preview process in the form of harmonization, unification, and consolidation of the conception of the Draft Provincial Regulation originating from the executive and simultaneously changing the structure of norm and placement of authority for the formation of regional regulations, especially within the ranks of the regional government as executor / holder of executive power in the regions.

In the procedure for the formation of regional regulations, the harmonization, unification, and consolidation of the conception of the Provincial Regional Regulation Draft is not the only abstract preview mechanism of the central government on the formulation of norms at the regional government level because Law Number 23 of 2014 has been amended several times recently by the Law Number 9 of 2015 and Permendagri Number 80 of 2015 as amended by Permendagri Number 120 of 2018 recognize other mechanisms related to abstract previews by the central government, namely the terms of evaluation, facilitation and provision of register numbers. ${ }^{29}$

The normative problem related to the participation of the central government in controlling norm-making at the regional government level through the abstract preview mechanism lies in the differences between the institutions that carry out the abstract preview. Procedures for harmonizing, unifying, and consolidating the conception of the draft regional regulation through Article 58 paragraph (2) of Law Number 15 of 2019 are carried out by institutions that carry out government affairs in the field of Formation of Legislations which in the event that they have not been formed are carried out by the Ministry that administers the affairs The government in the field of law in this case is the Ministry of Law and Human Rights, ${ }^{30}$ while for facilitation, evaluation and registration of numbers carried out by the Ministry of Home Affairs for the Draft Provincial Regulations and the Provincial Government as representatives of the central government in the regions for the draft district/city regional regulations This condition has the potential to cause institutional conflicts both between central government institutions and between state institutions at the central level and state institutions at the regional government level.

3. Implications of the provisions of Article 58 Paragraph (2) of Law Number 15 of 2019 on the Control Function of the Central Government through its Institutions/Ministries in Harmonizing, Consolidating and Rounding the Conception of Draft Regional Regulations Originating from the DPRD

The term statutory regulation in addition to having a substance in the form of a form but also has a meaning in the form of a process. ${ }^{31}$ The meaning of this statutory regulation is in line with the meaning of statutory regulations as stated in Article 1 number 2 of Law Number

\footnotetext{
${ }^{29}$ Evaluation are regulated in Article 242-245 Law Nomor 23/2014. Mechanism Facility regulated in Article 8790 Permendagri 80-2015.

30 Article 99A Law No. 15/2019.

${ }^{31}$ Soehino, 1981, Hukum Tata Negara: Teknik Perundang-undangan, Yogyakarta: Liberty, pg. 1.
} 
12 of 2011 which states that statutory regulations are written regulations which contain legally binding legal norms and are established or stipulated. By state institutions or authorized officials through the procedures stipulated in the Legislation. The process is an important part of categorizing a rule including statutory regulations or not in addition to the normalization aspect, in this sense it can be said that a unity of norms as a consequence of the hierarchy of laws and regulations also requires the existence of a single procedural unit for a type of statutory regulation.

The procedures for drafting regional regulations in Law Number 12 of 2011, especially in the stages of harmonization, unification and consolidation of the conception of the draft regional regulations have regulatory norm construction similar to the construction of regulatory norms for harmonizing, unifying and consolidating the conception of draft laws. The construction pattern of regulatory norms can be described as follows:

\section{Article 46}

(1)

(2) Harmonizing, unifying, and stabilizing the conception of the Draft Law originating from the DPR are coordinated by the DPR apparatus which specializes in the field of legislation.

\section{Article 47}

(1) $\ldots . . .$.

(2) Harmonizing, unifying, and stabilizing the conception of Draft Law originating from the President are coordinated by the minister who administers government affairs in the field of law.

(3) $\ldots$

(4) $\ldots$

Article 58

(1) Harmonizing, unifying, and stabilizing the conception of the Draft Provincial Regulation originating from Provincial DPRD are coordinated by the Provincial DPRD's apparatus that specializes in the field of legislation.

(2) Harmonizing, unifying, and consolidating the conception of Draft Provincial Regulations originating from the Governor are coordinated by a legal bureau and may include vertical agencies from the ministries that carry out government affairs in the legal sector.

From the description of the construction of these norms, it can be concluded that the mechanism of harmonization, unification, and consolidation of the conception between the draft law and the draft regional regulation has the same construction, which differs only in the level of institutions where the State only implements it, namely the central government and local governments but both represent the elements. The similarity of this normalization construction can be understood because regional laws and regulations are the only type of statutory regulation under the 1945 Constitution of the Republic of Indonesia, the preparation of which involves two institutions, namely the executive and the legislature. The diction used in formulating norms regarding harmonization, unification and strengthening of conception is also the same, namely the word "coordinated" where the word grammatically means regulating an organization or activity so that the rules and actions to be implemented do not conflict with each other. ${ }^{32}$

\footnotetext{
${ }^{32}$ Indonesia Dictionary, https://kbbi.web.id/koordinasi. 02 September 2020
} 
The construction of different norms regarding harmonization, unification and consolidation of conception between the draft law and the draft regional regulation took place after the enactment of Article 58 paragraph (2) of Law Number 15 of 2015 with the following constructs:

\section{Article 58}

(1) Harmonizing, unifying, and stabilizing the conception of the Draft Provincial Regulation originating from Provincial DPRD are coordinated by the Provincial DPRD's apparatus that specializes in the field of legislation.

(2) Harmonizing, unifying, and consolidating the conception of the Draft Provincial Regulation originating from the Governor is carried out by the ministry or institution that administers government affairs in the field of the Formation of Legislation.

Referring to the norm construction of the provisions of Article 58 paragraph (2) of Law Number 15 of 2019 and comparing it with other similar construction norms, namely those related to Harmonization, unification and consolidation of the conception of the draft law and the formulation of Article 58 paragraph (2) of the Law Number 12 of 2011 can be interpreted systematically $^{33}$ that Article 58 paragraph (2) has transferred the authority of harmonization, unification and consolidation of the conception of draft regional regulations from the regional government to the central government in this case to the institutions that carry out government affairs in the field of Regulatory Formation.

The diction or choice of words used in the provisions of Article 58 paragraph (2) of Law Number 15 of 2019 is the word "implemented" which is different from the diction in the provisions of Article 58 paragraph (2) before it is amended and is also different from the diction used in the provisions in Article 58 paragraph (1), Article 46 paragraph (2) and Article 47 paragraph (2) of Law Number 12 Year 2011 in which the diction used is the word "coordinated". If interpreted grammatically ${ }^{34}$ the word implemented which comes from the word "Laksana" means to do, to carry out, ${ }^{35}$ in this sense Article 58 paragraph (2) of Law Number 15 of 2019 means that harmonization, unification and consolidation of the conception of draft regional regulations are carried out by the institution that organizes governmental affairs in the field of Formulation of Legislation without requiring the involvement of the local government. It is different if we compare it with the diction before it is changed and the diction from other articles relating to harmonization, unification and strengthening of the conception, namely the "coordinated" diction as previously described, the word grammatically means "to regulate an organization or activity so that the rules and actions are will be implemented without contradicting each other", then in a word coordinated, the harmonization mechanism, unification and consolidation of the conception requires the involvement of parties other than the institution appointed as the coordinator. The difference in the meaning of these norms has the potential to cause problems at the normative level in the mechanism of harmonization, unification and strengthening of the conception of draft regional regulations; although at the level of implementation it can be tricked with cooperation and institutional closeness.

The strengthening of the role of the central government in controlling the formulation of regional regulatory norms in Article 58 paragraph (2) of Law Number 15 of 2019 is felt as

\footnotetext{
33 The method of systematic interpretation is interpretation according to the existing system in the formulation of the law itself (systematische interpretative). Systematic interpretation can also occur if one legal text and another legal text, in which both regulate the same thing, are linked and compared with one another. If for example what is being interpreted is an article of a law, then the same provisions, let alone one principle in another regulation, must be used as a reference. Utrecht, 1983, Introduction to Indonesian Law, adapted and revised by Moh. Saleh Djindang, cet. XI, Jakarta: PT. Ichtiar Baru, pg. 212-213. ${ }^{34}$ Grammatical interpretation is interpreting the words in laws according to the rules of language and the rules of grammar law. Jazim Hamidi, 2005, Hermeneutika Hukum, Yogyakata: UII Press, pg. 53.

${ }^{35} \mathrm{KBBI}$ online, https://kbbi.web.id/laksana, diakses tanggal 02 September 2020
} 
seen from the construction of norms that are different from other similar norms in Law Number 12 of 2011 and the use of different diction in the structure of the formation as described in the previous paragraph. The strengthening of the role of the central government is unfortunately placed on norms which actually do not have a comprehensive meaning for all regional regulations because in Article 58 paragraph (2) of Law Number 12 of 2011 before being amended, the harmonization, unification and consolidation of the conception of the draft regional regulation in that paragraph constitutes the distribution of mechanisms for harmonizing the draft regional regulations between those running in the DPRD (legislative) and the regional government (executive). So that when the normalization of Article 58 paragraph (2) is changed its construction and the authority to harmonize, unanimous and consolidate the conception of the draft regional regulation is transferred from the regional government to the central government in that article, making the position of the central government normatively not in the position of having the authority to conduct an abstract preview of all Regional regulations, however, are only limited to an abstract preview of the draft regional regulations which are proposals from the executive because in accordance with the provisions of Article 58 paragraph (1) the implementation of harmonization, unification and consolidation of the conception of draft regional regulations initiated by DPRD is still coordinated by the legislative body, namely Bappemperda.

The construction of norms Article 58 of Law Number 15 Year 2019 normatively lays down different procedures between the formation of regional regulations initiated by the DPRD and regional regulations submitted by the regional government. The draft regional regulation proposed by the regional head is absolutely necessary to carry out harmonization, unification and consolidation of its conception by the central government, while specifically the draft regional regulation initiated by the DPRD normatively does not require this. This kind of procedural difference is unusual in the form of central government control over the formulation of regional regulatory norms because one type of statutory regulation should have one formation procedure as a prerequisite for the birth of a single regulatory norm. If we compare the norms of Article 58 of Law Number 15 of 2019 with regulatory norms related to abstract preview in the form of facilitation, evaluation, and registration of draft regional regulations implemented by the Ministry of Home Affairs and the Provincial Government in Law Number 23 of 2014 and Permendagri Number 80 of 2015 and we interpret it systematically. ${ }^{36}$

\section{Conclusion}

Based on the description above, it can be concluded that several things related to the implications of the provisions of Article 58 paragraph (2) of Law Number 15 of 2019 on the mechanism of harmonization, unification and consolidation of the draft regional regulations, namely:

1. Normatively, the formulation of the provisions of Article 58 paragraph (2) of Law Number 15 of 2019 concerning Amendments to Law Number 12 of 2011 concerning the Formation of Laws and Regulations transfers the authority to harmonize, unify and consolidate the conception of draft regional regulations originating from parties executive to the central government from previously coordinated by the Legal Bureau/Legal Department, even the involvement of the Legal Bureau/Legal Department in the process was not explicitly stated because the diction used in Article 58 paragraph (2) of Law

\footnotetext{
${ }^{36}$ Systematic interpretation is determining the meaning or meaning of an article of legislation by linking it to other articles in the overall framework of the applicable legal system or regulations. Josef M Monterio., "Theory of Legal Discovery in Testing Laws of Government Regulations in Lieu of Laws", PRIORIS Law Journal, (Jakarta, Trisakti University Faculty of Law, 2018), pg. 272.
} 
Number 15 Year 2019 no longer uses the word "coordinated" but using the word "implemented."

2. Strengthening the function of the central government in conducting an abstract preview of the draft regional regulations as emphasized in Article 58 of Law Number 15 of 2019 is normatively meaningless to apply to the draft regional regulations initiated by the DPRD because the formulation of norms strictly limits itself to the draft regional regulations which originating from the executive and laying out norms regarding strengthening the role of the central government in harmonizing, unifying and stabilizing the conception put in the article that was originally put before amendment regulating differences in procedures for drafting regional regulations at DPRD institutions and local government agencies.

A. Book

\section{Bibliography}

Asshiddiqie, Jimly dan M. Ali Safaat, 2006, Theory Hans Kelsen Tentang Hukum, Cet I, Jakarta: Sekretariat Jendreral \& Kepaniteraan Makamah Konstitusi RI.

Asshiddiqie, Jimly, 2006, Pengantar Hukum Tata Negara Jilid II, Jakarta: Sekretariat Jenderal dan Kepaniteraan Mahkamah Konstitusi.

Asshiddiqie, Jimly, 2010, Perihal Undang-Undang, Jakrta: PT. Raja Grafindo Persada.

Ekathahjana, Widodo, 2008, Pengujian Peraturan Perundang-Undangan dan Sistem Peradilannya di Indonesia. Bandung: Pustaka Sutra.

Farida, Maria Indrati, 2002, Ilmu Perundang-Undangan: Jenis, Fungsi dan Materi Muatan, Yoyakarta: Kanisius.

Soehino, 1981, Hukum Tata Negara: Teknik Perundang-undangan. Yogyakarta: Liberty.

Utrecht, 1983, Pengantar Dalam Hukum Indonesia, disadur dan direvisi oleh Moh. Saleh Djindang, cet. XI, Jakarta: PT. Ichtiar Baru.

B. Journal

Arifin, 2015, "Eksistensi Peraturan Daerah Dlaam Sistem Hukum Nasional dan Implementasinya Terhadap Otonomi”, JURNAL ILMU HUKUM LEGAL OPINION, Palu: Fakultas Hukum Universitas Tadulako.

Arifin, Zainal Hoesein, 2011, "Pembentukan Hukum Dalam Perspektif Pembaharuan Hukum",Jurnal Rechts Vinding, Jakarta: Pusat Analisis dan Evaluasi Hukum Nasional Badan Pembinaan Hukum Nasional Kementerian Hukum dan HAM RI.

Asmawi, 2014, "Dewan Perwakilan Rakyat Daerah (DPRD) Dalam Perundang-Undangan Pemerintahan Daerah dan Lembaga Legislatif Daerah". Jurnal Cita Hukum, Jakarta: Fakultas syariah dan Hukum Universitas Islam Negeri Syarif Hidayatullah Jakarta.

Dwi, Bayu Anggono, 2010, "Harmonisasi Peraturan Perundang-Undangan di Bidang Penanggulangan Bencana,MIMBAR HUKUM, Yogyakarta: Fakultas Hukum Universitas Gajah Mada.

Firdaus; Donny Michael, 2019, "Implementasi Peraturan Menteri Hukum dan HAM Nomor 23 Tahun 2018 tentang Pengharmonisasian Rancangan Peraturan Menteri, Rancangan Peraturan Lembaga Pemerintah Non Kementerian Atau Rancangan Peraturan Dari Lembaga Non structural Oleh Perancang Peraturan Perundang-Undangan”, Jurnal Penelitian Hukum De Jure, Jakarta: Badan Penelitian dan Pengembangan Hukum dan HAM Kementerian Hukum dan HAM RI.

Gusman, Delfina, 2011, "Urgensi Naskah Akademik Dalam Pembentukan Peraturan PerundangUndangan yang Baik",Masalah-Masalah Hukum, Semarang: Fakultas Hukum Universitas Diponegoro.

Huda, Ni'matul, 2006, "Kedudukan Peraturan Daerah Dalam Hierarki Peraturan PerundangUndangan",Jurnal HukumIUS QUIA IUSTUM, Yogyakarta: Fakultas Hukum Universitas Islam Indonesia. 
M, Josef Monterio, 2018, “Teori Penemuan Hukum Dalam Pengujian Undang-Undang Peraturan Pemerintah Pengganti Undang-Undang",Jurnal Hukum PRIORIS, Jakarta, Fakultas Hukum Universitas Trisakti.

Mahrus, Mohammad Ali, 2015, "Konstitusionalitas dan Legalitas Norma dalam Pengujian Undang-Undang Terhadap Undang-Undang Dasar 1945”, Jurnal Konstitusi, Jakarta: Kepaniteraan dan Sekretariat Jenderal Mahkamah Konstitusi Republik Indonesia.

Prapti, Derita Rahayu, 2015, "Pengawasan Preventif Sebagai Kontrol Pusat Terhadap Daerah di Era Reformasi".PADJAJARAN Jurnal Ilmu Hukum, Bandung, Fakultas Hukum Universitas Padjajaran.

Pratama, Nanda Sukoco, 2012, "Peran Badan Legislasi Dalam Pembentukan Peraturan Daerah Inisiatif Dewan Perwakilan Rakyat Daerah Provinsi Jawa Timur", Jejaring Administrasi Publik, Surabaya: Fakultas Hukum Universitas Airlangga.

Siallagan, Haposan, 2016, "Penerapan Prinsip Negara Hukum di Indonesia", Sosiohumaniora, Bandung: Unpad Press.

Simanjuntak, Enrico, 2016, "Pengujian Perda dan Perdes Pasca Perubahan UU Pemda dan UU Desa", Jurnal Konstitusi, Jakarta: Kepaniteraan dan Sekretariat Jenderal Mahkamah Konstitusi Republik Indonesia.

Sina, Ibnu Chandranegara, 2019 "Bentuk-Bentuk Perampingan dan Harmonisasi Regulasi". Jurnal Hukum IUS QUIA IUSTUM, Yogyakarta: Fakultas Hukum Universitas Islam Indonesia.

Supriyadi, 2016, "Peraturan Daerah, Antara Kepentingan Pemerintah Pusat dan Pemerintah Daerah",Jurnal Cakrawala Hukum, Malang: Universitas Merdeka.

Syaprillah, Aditia, 2019, "Strategi Harmonisasi Penyusunan Peraturan Daerah Melalui Mekanisme Executive Preview. Borneo Law Review, Tarakan: Pasca Sarjana Magister Hukum Universitas Borneo Tarakan.

C. Internet

Dirjen Otonomi Daerah Kementerian Dalam Negeri "Perda Tumpang Tindih denga aturan yang Lebih Tinggi", https://mediaindonesia.com/read/detail/211482-kemendagri-25-perdatumpang-tindih-dengan-aturan-yang lebih-tinggi, diakses tanggal 02 September 2020. https://kbbi.web.id/koordinasi. 
